\title{
DMU40 MEGMUNKÁLÓ KÖZPONT VIZSGÁLATA I. ÁTTEKINTÉS
}

\author{
Kiss Róbert \\ tervezömérnök, Diehl Aviation Hungary Kft. \\ 4300 Nyírbátor, Ipari Park utca 9, e-mail: robert.kiss9405@gmail.com \\ Szilágyi Attila \\ egyetemi docens, Miskolci Egyetem, Szerszámgépészeti és Mechatronikai Intézet, \\ Szerszámgépek Intézeti Tanszéke \\ 3515 Miskolc, Miskolc-Egyetemváros, e-mail: szilagyi.attila@uni-miskolc.hu
}

\begin{abstract}
Absztrakt
Ez a cikk az elsö fejezete egy szerszámgép komplex dinamikai vizsgálatát bemutató cikksorozatnak, és általánosságban tekinti át a gépvizsgálati folyamat elméleti, numerikus és kísérleti módszereit. Ez utóbbiakat - szándékunk szerint - több, egymásra épülö cikkek sorozataként mutatjuk be. Vizsgálataink a Szerszámgépek Intézeti Tanszékének mühelycsarnokában található DMU 40 5-tengelyes CNC megmunkálóközpont dinamikai tulajdonságainak feltárására vonatkoznak. Vizsgálataink középpontjában a berendezés dinamikai merevsége összetevöinek értékét kivánjuk megbecsülni a berendezés sajátfrekvenciáinak értékein keresztül, melyeket analitikus, numerikus, illetve kísérleti módszerek segitségével határozunk meg.
\end{abstract}

Kulcsszavak: sajátfrekvencia, DMU 40, VEM, analitikus módszer, dinamikai merevség, ANSYS WB 19.1

\begin{abstract}
This note is the first part of an extended research-analysis work, where our aim is to summarize the concepts of the methods and measurements, which we will present in the later articles. The research is focusing on the dynamic behavior of the DMU 40 5-axis CNC machine center, which can be found in the workshop of the Department of Machine Tools. This means that we would like to determine the magnitude of the dynamic stiffness of the machine tool, by calculating the value of the natural frequencies by final element method (analytically, and with software), and with the help of an experimental test.
\end{abstract}

Keywords: natural frequency, DMU 40, FEM, analytical method, dynamic stiffness, ANSYS WB 19.1

\section{Bevezetés}

A dinamikai vizsgálat alapjául a Szerszámgépek Intézeti Tanszékének mühelycsarnokában található DMU 40 fúró-maró megmunkálóközpont szolgál. Az 1. ábra mutatja a berendezést, illetve annak burkolatok nélküli - szerkezeti felépítését. Az 1. ábra baloldali struktúrájának 3D-s geometriai modelljét alkalmazzuk elméleti vizsgálataink során. Az analitikus vizsgálatok mellett a berendezés müszeres rezgésvizsgálatát is elvégezzük, amely hasznos alapot nyújt az elméleti eredmények, így az elméleti eljárások validálásához. A 2. fejezet alfejezetei röviden összefoglalják az alkalmazott vizsgálati módszerek jellemzöit, alkalmazásuknak módjait. 
Alapvetően három különböző eljárást alkalmazunk vizsgálataink során:

- Véges sok szabadságfokú rezgőrendszer analitikus vizsgálata (röviden a 2.1. fejezetben érintjük),

- A numerikus mechanika eszközei közül a végeselem-módszer (ANSYS WB 19.1), röviden a 2.2. fejezetben érintjük,

- Kísérleti eljárás müszeres rezgésvizsgálaton keresztül, melyet a 2.3. fejezetben tekintünk át röviden.
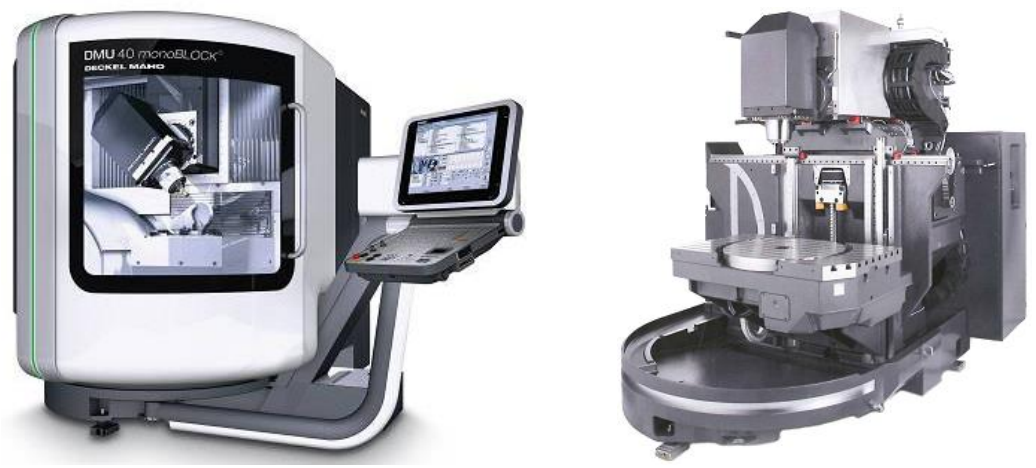

1. ábra. A vizsgálatba vont DMU 40 megmunkálóközpont [1]

\section{Az egyes eljárások rövid bemutatása}

Az alábbiakban a további vizsgálataink hátterét képező eljárások elméleti alapjait mutatjuk be, illetve röviden utalunk azok alkalmazásának módjára is. Az egyes módszerek részletesebb elméleti háttere például a [4][5] müvekben tanulmányozható. Részletesebb kifejtésre az említett cikksorozat későbbi részeiben térünk ki.

\subsection{Az analitikus eljárás}

A fizikai világ bonyolultsága miatt a fellépő jelenségek értelmezése sokszor csak modellek segítségével végezhető. A modellek a vizsgált jelenség - vizsgálat szempontjából - lényeges tulajdonságait veszik figyelembe. A mechanikai jelenségek vizsgálata során leggyakrabban alkalmazott modellek a rúd-, lemez-, tömegpont-, és a merevtest modellek. Mechanikai rezgések vizsgálata során sokszor jóval bonyolultabb modellek szükségesek, mint a mechanika más területein. A modellalkotás egyik kulcspontja a mechanikai modellt követő matematikai modell, amely lényegében a vizsgált jelenség mozgásegyenlet-rendszerének a felírását jelenti. A 2. ábra a mechanikai modellalkotás általános sémáját mutatja.

A folyamat fő lépései az alábbiak szerint foglalhatók össze:

1. A vizsgált berendezés, jelenség mechanikai modelljének felállítása, paraméterhalmaz megadása,

2. A mechanikai modell matematikai modelljének felállítása (mozgásegyenletek differenciálegyenlet-rendszer alakjában történő felírása),

3. A mozgásegyenlet-rendszer - valamilyen módszerrel történő - megoldása,

4. A számítás eredményeinek - általában - diagram formátumú megjelenítése, azok vizsgálata, értékelése,

5. Következtetések, a modell finomítása, illetve a vizsgált fizikai objektum módosítása. 


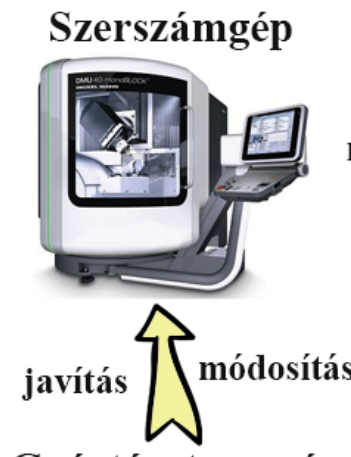

Gyártás, tervezés

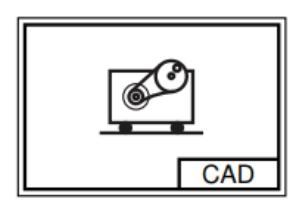

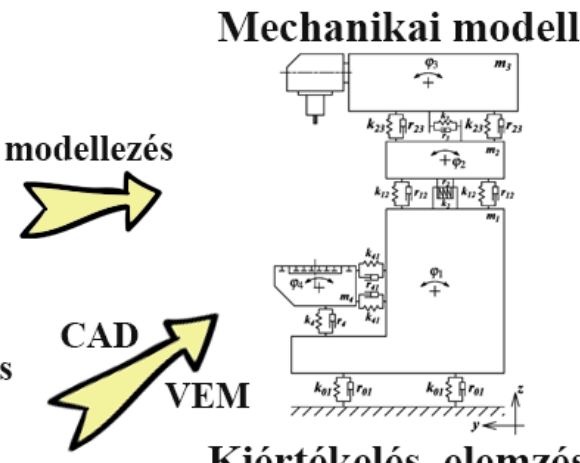

Kiértékelés, elemzés
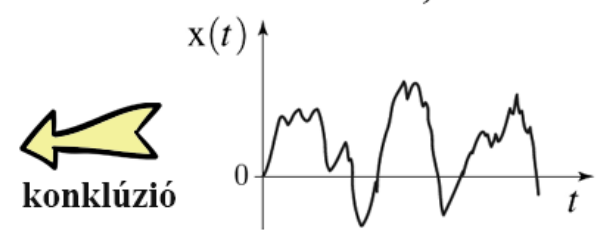

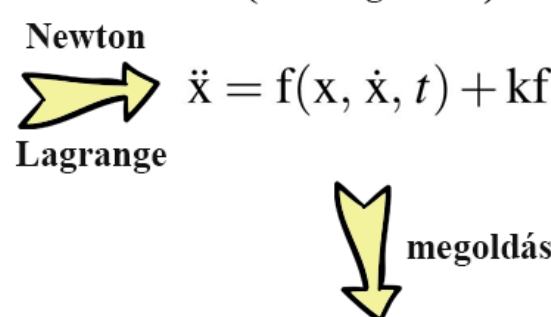

Eredmények

$$
\mathrm{x}=\mathrm{x}(t)
$$

2. ábra. Mechanikai modell alkotásának folyamata [3]

A folyamat fó lépései az alábbiak szerint foglalhatók össze:

6. A vizsgált berendezés, jelenség mechanikai modelljének felállítása, paraméterhalmaz megadá$\mathrm{sa}$,

7. A mechanikai modell matematikai modelljének felállítása (mozgásegyenletek differenciálegyenlet-rendszer alakjában történő felírása),

8. A mozgásegyenlet-rendszer - valamilyen módszerrel történő - megoldása,

9. A számítás eredményeinek - általában - diagram formátumú megjelenítése, azok vizsgálata, értékelése,

10. Következtetések, a modell finomítása, illetve a vizsgált fizikai objektum módosítása.

Egy megmunkálóberendezés konstrukciós folyamatának már korai fázisában helyet kapnak különféle modellezési vizsgálatok, melyeket általában a kinematikai és dinamikai viszonyok feltárására alkalmaznak. Berendezések analitikus vizsgálata - még a legegyszerúbb esetekben is - bonyolult mozgásegyenlet-rendszer megoldására vezet. Ilyen matematikai modellek klasszikus (Newton-Euler, Lagrange) módszerekkel történő megoldása közismert nehézségekbe ütközik. Éppen ezért, az elmúlt évtizedek során elterjedt matematikai szoftvereknek köszönhetően, az ilyen bonyolultságú modellek kellő pontosságú megoldása a matematika numerikus eszközeivel vált lehetővé.

\subsection{A végeselem-módszer - ANSYS WB 19.1}

Sok esetben a berendezések szilárdságtani analízise igényli végeselem-módszer (VEM) alkalmazását. Ennek során a gépészmérnöki gyakorlat olyan gépelemek, egységek szerkezeti analízisét végzi el, amelyek általában egy teljes megmunkálóberendezés, esetleg erő- és munkagép, illetve közlekedési eszköz részét képezik. Számítások során elöször az ismeretlen elmozdulásmezőt határozzuk meg, majd ennek ismeretében számíthatók további mennyiségek, például deformációk, mechanikai feszültségek, alakváltozási energiák, reakcióerök. 

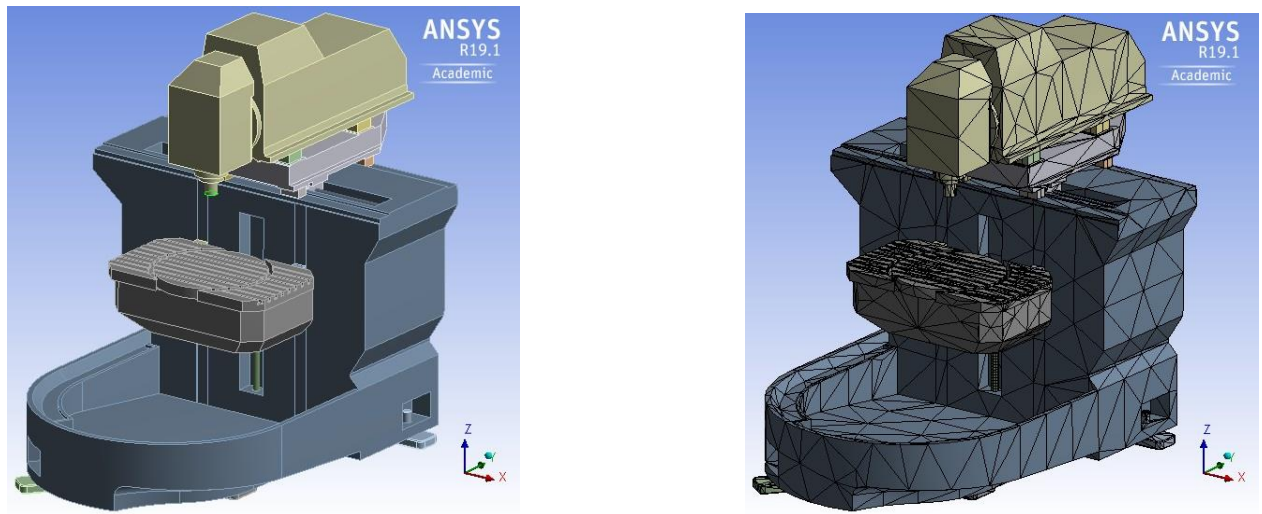

3. ábra. 3D-s geometriai modell és annak végeselem-hálója [2]

A leggyakrabban előforduló mérnöki problémák:

- Statikus szilárdságtani vizsgálatok: Állandó terhelés hatására bekövetkező, időben állandó alakváltozások, mechanikai feszültségek, reakcióerők meghatározása. Mindezek mellett a modell tartalmazhat időben állandó tehetetlenségi terhelést (állandó szögsebességü forgás, gravitációs erö), időben lassan változó terheléseket, vagy esetleg időben szintén lassan változó anyagtulajdonságokat (pl. kúszás jelensége).

- Modálanalízis: Ennek segítségével a vizsgálatba vont szerkezet rezgésjellemzőit határozhatjuk meg, számíthatjuk ki annak sajátfrekvenciáit, illetve a vonatkozó rezgésképeket. A modálanalízis további összetett dinamikai vizsgálatok alapjául szolgálhat (tranziens jelenségek, harmonikus gerjesztések, spektrumanalízis).

- Válaszfüggvény analízis: Időben ciklikusan változó terhelésre adott állandósult állapotú válaszfüggvény előállítása. Ekkor a terhelésfelvétel során fellépő tranziens jelenségek hatását figyelmen kívül hagyjuk. E számítások alapján a szerkezet hosszútávú dinamikai hatásokra vonatkozó állapota vizsgálható, például a rezonáns viselkedés és a kifáradási hajlam. A számítás első eredménye mindig az amplitúdó-frekvencia függvény, illetve annak diagramja (rezonanciagörbe).

- Spektrumanalízis: A modálanalízis kiterjesztett változata. Determinisztikus, illetve sztochasztikus gerjesztések hatására bekövetkező rezgések során megjelenő elmozdulások, alakváltozások, mechanikai feszültségek meghatározása.

\subsection{A sajátfrekvenciák kísérleti meghatározása}

Az egyes berendezések sajátfrekvenciáinak ismerete sok szempontból is fontos. Egyrészt, ezek ismeretében könnyebben felismerhetők bizonyos hibaokok, amelyek időben történő kiiktatása fölösleges káresetektől mentesít, illetve tervezési fázisban lehetőség van javító konstrukciós módosításokra. Üzemi körülmények között pedig folyamatos állapotfelügyeletet tesz lehetővé. A berendezés valós rezgésállapotának ismeretében átfogó képet kaphatunk annak állapotáról, illetve a megmunkált alkatrész pontosságáról is.

Egy berendezés állapotfelügyelete során általában három jellemző rezgésvizsgálat zajlik:

- Csapágyrezgések detektálása,

- Rezonancia vizsgálatok,

- Kinematikai analízis. 
A továbbiakban, elméleti és kísérleti vizsgálataink során kizárólag a rezonáns állapotok vizsgálatára szorítkozunk. Két eljárást alkalmazunk ennek során: fel- és lefutási vizsgálatot, illetve a külső gerjesztés módszerét. Az első eljárást általában forgó mozgást végző berendezések rezonáns állapotának vizsgálatára alkalmazzák. A második módszert, célzott gerjesztési tartomány mellett, szerszámgépek, és jármüvek vizsgálata során alkalmazzák. A 4. ábra a külső gerjesztéses módszer sémáját mutatja, amit egyébként kísérleti vizsgálataink során mi is alkalmazni fogunk.

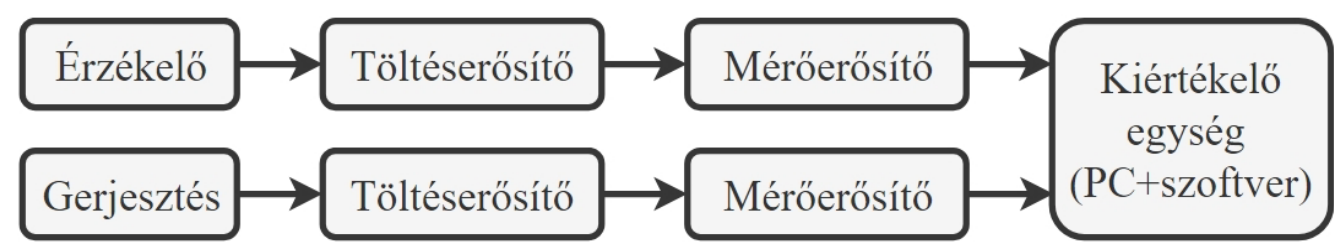

4. ábra. A külső gerjesztéses eljárás blokkvázlata [2]

\section{3. Összefoglalás}

A fentiek alapján tehát számos - elméleti és kísérleti - módszer áll rendelkezésre szerszámgépek dinamikus merevségének meghatározására. Ennek ismerete a berendezésen elóállított termékek pontossága szempontjából lényeges. Pontos megmunkálás és optimális felületi érdesség elérése érdekében, megmunkálás során, a rezonáns állapot kerülendő.

\section{Köszönetnyilvánítás}

A cikkben ismertetett kutató munka az EFOP-3.6.1-16-2016-00011 jelü „Fiatalodó és Megújuló Egyetem - Innovatív Tudásváros - a Miskolci Egyetem intelligens szakosodást szolgáló intézményi fejlesztése" projekt részeként - a Széchenyi 2020 keretében - az Európai Unió támogatásával, az Európai Szociális Alap társfinanszírozásával valósul meg.

\section{Irodalom}

[1] DMU monoBLOCK Series catalogue, https://www.dmg.com, Letöltve: 2018.01.26.

[2] Kiss, R.: CNC megmunkáló központ dinamikai viselkedésének vizsgálata végeselemmódszerrel, Diplomaterv, Miskolc, 2019.

[3] Csernák, G., Stépán, G.: A müszaki rezgéstan alapjai. Egyetemi jegyzet, Budapest, BME, 2012.

[4] Dömötör, F.: Rezgésdiagnosztika I., Dunaújvárosi Főiskola, Dunaújváros, 2008.

[5] Pascal, M.: Parallelization of Design and Simulation: Virtual Machine Tools in Real Product Development. Doctoral Thesis, ETH Zürich, 2012. 